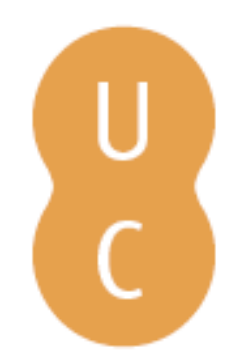

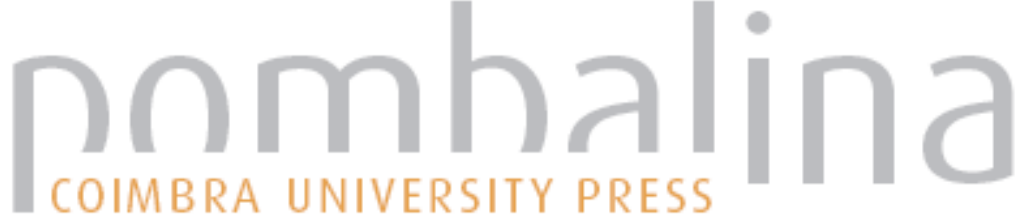

\section{Youth soccer: a biocultural perspective}

\author{
Autor(es): $\quad$ Cumming, Sean P; Standage, Martyn; Malina, Robert M \\ Publicado por: Coimbra University Press \\ URL \\ persistente: URI:http://hdl.handle.net/10316.2/32631 \\ DOI: $\quad$ DOI:http://dx.doi.org/10.14195/978-989-26-0412-1_15
}

Accessed : $\quad$ 26-Apr-2023 09:06:31

A navegação consulta e descarregamento dos títulos inseridos nas Bibliotecas Digitais UC Digitalis, UC Pombalina e UC Impactum, pressupõem a aceitação plena e sem reservas dos Termos e Condições de Uso destas Bibliotecas Digitais, disponíveis em https://digitalis.uc.pt/pt-pt/termos.

Conforme exposto nos referidos Termos e Condições de Uso, o descarregamento de títulos de acesso restrito requer uma licença válida de autorização devendo o utilizador aceder ao(s) documento(s) a partir de um endereço de IP da instituição detentora da supramencionada licença.

Ao utilizador é apenas permitido o descarregamento para uso pessoal, pelo que o emprego do(s) título(s) descarregado(s) para outro fim, designadamente comercial, carece de autorização do respetivo autor ou editor da obra.

Na medida em que todas as obras da UC Digitalis se encontram protegidas pelo Código do Direito de Autor e Direitos Conexos e demais legislação aplicável, toda a cópia, parcial ou total, deste documento, nos casos em que é legalmente admitida, deverá conter ou fazer-se acompanhar por este aviso.

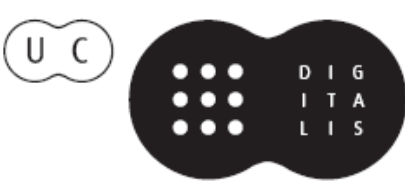


MANUEL COELHO E SILVA

ROBERT M. MALINA

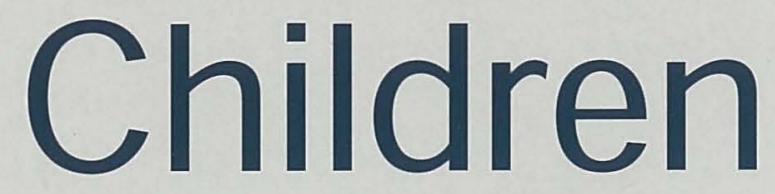

\section{and Youth}

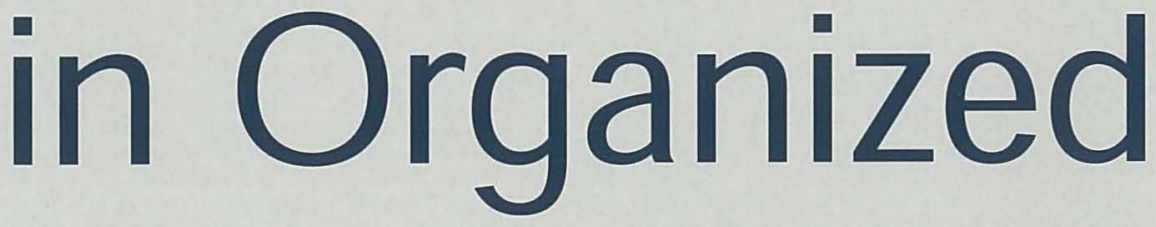

Sports 
(Página deixada propositadamente em branco) 
Manuel Coelho e Silva

Robert M. Malina

(Editors)

CHILDREN AND YOUTH IN ORGANIZED SPORTS

COIMBRA UNIVERSITY PRESS

2004 


$$
\begin{gathered}
\text { Editors } \\
\text { Manuel Coelho e Silva } \\
\text { and } \\
\text { Robert M. Malina } \\
\text { Publisher } \\
\text { Imprensa da Universidade de Coimbra } \\
\text { Coimbra University Press } \\
\text { Title } \\
\text { Children and Youth in Organized Sports }
\end{gathered}
$$

Date

March 2004

ISBN

972-8704-21-6

(Depósito legal n.: 208058/04)

Financial support

FCT Fundação para a Ciência e a 'Tecnologia MINISTÉRIO DA CIÊNCIA E DO ENSINO SUPERIOR Portugal

$$
\text { Apoio do Programa Operacional }
$$

Ciência, Tecnologia, Inovação do Quadro Comunitário de Apoio III

e

Câmara Municipal da Lousã

Faculdade de Ciências do Desporto e Educação Física

Universidade de Coimbra 


\section{YOUTH SOCCER: A BIOCULTURAL PERSPECTIVE}

\section{Sean P Cumming}

Department of Psychology. University of Washington. Seattle. WA.

UNITED STATES OF AMERICA

Martyn Standage

Department of Sport and Exercise Science. University of Bath

UNITED KINGDOM

\section{Robert M Malina}

Fellow of the American College of Sports Medicine. Research Professor. Tarleton State University. Stephenville. TX

UNITED STATES OF AMERICA

\section{QUESTIONS TO CONSIDER?}

- What are the growth and maturity characteristics of young soccer players?

- How does growth and maturation impact upon the socialization process in youth soccer?

- Does maturity status act as an exclusionary factor in elitist youth soccer programs?

- How does maturity status influence the nature and quality of young soccer players' interactions with adults?

"It's a game of athleticism, a game of power and competition and strength. Anybody who thinks football is just a game of deftness of touch without those other things wouldn't win".

Sir Bobby Robson, professional soccer manager.

If one is to understand participation behavior and performance in youth soccer, it is important to recognize the contribution and interaction of various biological, psychological and cultural factors. Sport may be a social phenomenon, but the biological organism performs within a particular cultural context (Malina, 2002). Researchers studying the socialization process in youth soccer would do well to adopt a biocultural perspective. To date, however, few psychologists or sociologists have examined the contribution of biological or maturational factors upon the socialization process in youth sport (Weiss and Glenn, 1992). With this in mind, the purpose of this chapter is to review the extant literature and discuss theoretical and research issues as they relate 
to the biological maturity status of young soccer players and how it may impact upon the socialization process in the sport.

\section{THE MEDIATED EFFECTS MODEL OF PSYCHOLOGICAL AND BEHAVIORAL ADAPTATION TO PUBERTY}

The mediated effects model of adaptation to puberty assumes that the psychological and behavioral effects of puberty are mediated by the individual's "... ideation about his or her biological changes and the subjective meaning or affective significance attributed to them" (Peterson and Taylor, 1980, p. 137). In short, the effects of pubertal changes are mediated by intervening variables or moderated by exogenous or contextual factors. Young athletes' subjective evaluations of their maturational development may be partially derived from cues in their immediate social environments (e.g., parents, peers, coaches, administrators). Research examining the psychological and behavioral consequences of early and late maturation has shown that the peer and parental environments are especially instrumental in determining adolescent satisfaction with bodily changes change (Blyth et al., 1985; Faust, 1983; Peterson and Taylor, 1980).

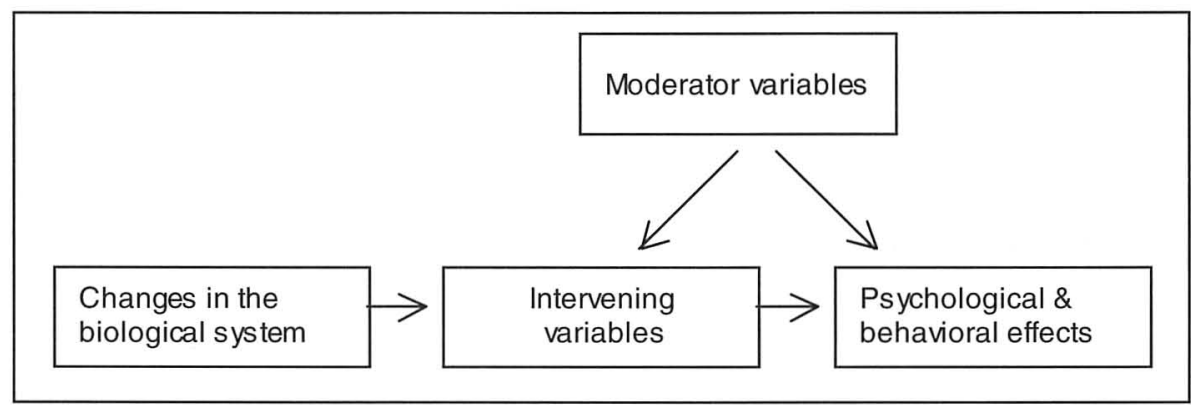

Figure I. Mediated Effects Model of Psychological and Behavioral Adaptation to Puberty (Adapted from Peterson and Taylor, 1980)

Maturity associated changes in height, weight, body composition, and physical aptitude may have significant social stimulus value for male and female

210 athletes. The evaluations, reactions, and impressions conveyed by parents, peers, coaches, and/or administrators may directly or indirectly communicate positive or negative information regarding physical appearance, competence or autonomy. Adults rate early maturing males as having superior physiques and physical abilities (Jones and Bayley, 1950). This tendency is most evident beyond the age of 14 years. Little information is available on how adults rate the physical characteristics or aptitude of early and late maturing females. Research does, however, suggest that the family environment is influential in helping females adjust psychologically and behaviorally to the physical changes 
associated with maturation (Brooks-Gunn and Ruble, 1983). Similarly, the reactions of significant others, i.e., peers, educators, family, and so on, are instrumental in determining the perception of adolescent females own physical attractiveness (Schonfeld, 1964).

\section{GROWTH AND MATURITY CHARACTERISTICS OF YOUNG SOCCER PLAYERS}

The size, physique, and functional characteristics of young athletes typically reflect the demands of specific sports. To this end, soccer is a sport that requires a high degree of both skill and athleticism. The height, mass and biological maturity status of male youth soccer players has been documented in a number of European, Latin American and North American countries (Malina, in press). The average heights and weights of samples of male youth soccer players, most of which could be classified as elite, fluctuate about the reference medians for the general population from childhood through midadolescence. In later adolescence, however, average heights of male soccer players typically fall at or below the reference medians, while mean weights continue to fall above the reference medians. The greater weight-for-height of soccer players most likely reflects an increase in the proportion of fat-free mass (i.e., muscle mass) and a dominantly mesomorphic physique (Malina, in press; Carter and Heath, 1990).

Male youth soccer players are, on average, typically advanced in biological maturity status, particularly after the age of 13 years (Malina et al., 2000; Malina, in press). This is not surprising; advanced maturity in males is associated, on average, with larger stature, body mass and fat-free mass, and greater physical competence as reflected in standardize performance tasks of speed, strength, power, and so on. Italian youth soccer players, when compared with control samples, were more advanced in biological maturity status (skeletal and genital), particularly after 12- I 3 years of age (Mazanti et al., 1989). Mexican (Peña-Reyes et al., 1994) and Portuguese (Malina et al., 2000) male soccer players were advanced in skeletal maturity after 13-14 years of age. The advanced maturity status of young soccer players was especially apparent during mid-adolescence (13-15 years), which is the interval of the adolescent growth spurt in the majority of boys. In later adolescence, there is catch-up of later maturing boys so that maturity-associated variation in size and performance is reduced.

Despite the growing popularity of women's soccer, little information exists on the growth and maturation of female youth soccer players. The few studies that have been conducted with female soccer players indicate that from late childhood to early adulthood the heights of female soccer players are, on average, marginally above the median reference values for their age 
(Cumming, 2002; Siegel, 1995). Across all ages, the female soccer players also tend to have longer legs than the general population (Siegel, 1995). The weights of female soccer players typically fall at or above median reference values, except in later adolescence and early adulthood when the weight of the players is consistently above the reference median (Cumming 2002; Siegel, 1996). In late childhood and early adolescence the weight-for-height of female soccer players, as expressed by the body mass index $\left(\mathrm{BMl}, \mathrm{kg} / \mathrm{m}^{2}\right)$, varies above and below the median reference values for the general population. Between the period of late adolescence and early adulthood, however, the $\mathrm{BMI}$ of female soccer players is typically above reference medians (Cumming, 2002; Siegel, 1996), indicating as in male soccer players proportionally more weight-for-height. The somatotypes of female soccer players are reasonably well=balanced in late childhood and adolescence between. In early adulthood, however, players tend to be, on average, mesomorphic endomorphs (Siegel et al., 1996).

Although data are limited, female soccer players, like female athletes in many team sports, tend to approximate the average, i.e., are "on time," in biological maturity status (Malina, 1983, 2002; Malina et al., in press). The data for female players are based on the age at menarche, which is a late event in the adolescent sequence of pubertal events. Menarche occurs, on average, about one year after peak height velocity (Malina et al., in press). As noted earlier and in contrast to female soccer players, male soccer players tend to be advanced in biological maturity (skeletal age and sexual maturation).

\section{THE IMPACT OF BIOLOGICAL MATURITY STATUS UPON THE SOCIALIZATION PROCESS IN YOUTH SOCCER}

The physical and functional characteristics associated with maturity status may have significant social stimulus for coaches, administrators, and/or parents. Early maturing males and average-to-late maturing females have, on average, physiques and functional characteristics that are more suitable for success in soccer. Soccer is a sport that requires aerobic and muscular endurance, speed, power and agility, and characteristics associated with late

212 maturation in boys and early maturation in girls are associated, on average, with poorer levels of physical performance in these functional requirements of soccer. This does not mean that all late maturing boys and early maturing girls are excluded from the sport because of their maturity status. Rather, they are simply less likely to be represented in the sport at more successful or elite levels during adolescence. Indeed, the challenge for adults who train and develop youth soccer players is to provide opportunities for the skilled late maturing boy and skilled early maturing girl to experience success in the sport so that their motivation will be maintained and they will persist in the sport. 
Players who are more successful or who have greater physical potential for success in a sport, specifically soccer, may receive greater encouragement from adults to play, more positive feedback, and more opportunities to further develop their skills (i.e., access to better coaches, invitations to play for elite level programs or attend elite player development camps). Indeed, perceptions of positive coaching behavior were positively correlated with soccer self-esteem in a sample of Norwegian male youth soccer players (Ommundsen and Vaglum, 1991a).

Greater physical potential for success in soccer, however, does not always result in more favorable reactions from adults. High expectations for success may lead adults to exert a greater degree of pressure or control over youth who are physically more gifted for playing soccer. Male soccer players who were older and more advanced in maturity status were more likely to perceive their coaches as controlling as opposed to being supportive of autonomy. In contrast to the observations for males, estimated maturity status of female soccer players was unrelated to perceptions of autonomy support from coaches or parents (Cumming, 2002). Previous sport-based research has also shown that coach-created situations perceived by athletes as controlling (i.e., being told what to do and how to do it) undermine the intrinsic motivation, creativity, and self-expression of athletes (Vallerand, 200 I).

Biological maturity may also act as an exclusionary factor in youth soccer, particularly males. Elite youth soccer programs may systematically exclude male players on the basis of maturity status (Malina, 2002). A study of males playing for several elite male youth soccer teams in Portugal indicated an equal proportion of early and late maturing players prior to 13 years of age (Malina et al., 2000). The proportion of early maturing males, however, increased significantly in the older adolescent age groups (i.e., 13-16 years). Similarly, in a study comparing the estimated maturity status of male youth soccer players competing in travel and recreational soccer programs in MidMichigan (U.S.), males playing travel soccer were more advanced in maturity status (Cumming, 2002).

Corresponding data for females are very limited, and comparisons of elite and non-elite female soccer players are lacking. Some data limited to estimated maturity status based on predicted adult height suggest no differences in the maturity status of females in recreational and more competitive travel programs (Cumming, 2002). More research is warranted to ascertain the potential exclusionary impact of variation in biological maturity status in female youth soccer programs. Although maturity status may not act as an exclusionary factor in more elite level programs for females, it may act to 
exclude females from general participation in soccer which may have implications for patterns of habitual physical activity.

Maturity-associated variation in size, muscularity and physical competence is most evident between the ages of $1 \mathrm{I}$ and 13 years in females and 13 and 15 years in males. However, such variation begins to manifest itself in the years immediately preceding, the initiation of the transition into adolescence for most girls and boys, about $9-10$ and $11-12$ years, respectively (Malina et al., in press). Issues related to the potential impact of maturity status per se and associated changes in size, body composition and performance upon motivated behavior and treatment of talented young athletes need more systematic attention in the sport psychology research community.

The chronological age of a child and the range of the age group for competition may accentuate the impact of variation in biological maturity status on the processes of inclusion and exclusion in soccer and other sports. This is related to when a youngster is born within the selection or competitive year. At present in soccer, January I marks the beginning of the selection or competitive year (it is August I for Little League Baseball). Male youth soccer players who are born in early in the selection year are thus the oldest children in an age group and are more likely to be identified as talented, to be exposed to higher levels of coaching, and to be represented more often at the professional and national levels. Players who are born in the later quarter of the selection year tend to drop out of soccer, either voluntarily or perhaps systematically, around the age of 12 years (Helsen et al., 1998). This phenomenon is referred to as the 'season-of-birth bias' (Simmons and Paull, 200I). It has been observed in elite youth and professional adult soccer players in the Netherlands, England, Belgium, Sweden, Germany, Brazil, Japan, and Australia (Brewer et al., 1995; Helsen et al., 1998; Musch and Hay, 1999; Simmons and Paull, 200I). The season-of-birth bias also shifts with start date of the competitive year. In England, the selection year starts in September. The majority (58.7-71.8\%) of players selected for the English Football Associations centers of excellence were born between September and December (Brewer et al., 1995). In Sweden, where the selection year starts in January, the majority of male soccer players (62.2-62.7\%) were born between January and April. In a sport such as soccer, where greater physical size and functional capacity are generally desirable, players born early in the competitive year have a distinct advantage.

The manner in which players are grouped may also accentuate the impact of age and biological maturity status upon the processes of inclusion and exclusion. The majority of youth soccer programs in the United States group competitors by chronological age, typically using two-year age brackets 
(e.g., | |- 12 [1 | $.0-12.9]$ years, or 13-14 [13.0-14.9] years). In addition to a relatively broad range of variation in chronological age within the age group, players vary considerably in biological maturity status. Indeed, an II year old boy who is late in maturity and a 12 year old boy who is advanced in maturity may vary by as much as 4 or 5 years in biological age (Malina et al., in press). Many soccer programs in Europe, particularly those in communities where there are a limited number of children, group players relative to an upper age limit (e.g., under 16 years, under 17 years). This allows for more players within a broader age range. However, the broader the age range, the greater the potential impact of chronological age per se (which often translates into experience in the sport) and biological maturity status on the processes of inclusion and exclusion in the sport.

Players who are younger and/or later in biological maturation may struggle to compete against youth who are older and/or more advanced in maturity. These players may become discouraged and drop out of the sport, or they may be systematically excluded by the sport. Note, however, that in later adolescence (17-18 years of age), the differences in size and performance among boys of contrasting maturity status are reduced considerably. Indeed, it is often the later maturing boy who attains a greater height in young adulthood (Malina et al., in press). A question of interest is the following: Are talented later maturing boys excluded from the sport due in part to the size, strength and power disadvantage associated with their maturity status early in adolescence, and in part to the preferences of coaches for larger, more powerful boys who tend to be advanced in biological maturity? A related question that needs attention is the following: How can the sport retain or protect skilled smaller, later maturing boys as they progress through adolescence?

Corresponding questions regarding the socialization and/or selection of girls for soccer have not yet surfaced. Nevertheless, the potential impact of issues raised in the context of boys' programs needs consideration in programs for girls.

The physical characteristics of young soccer players may also influence the amount of playing time and coach attention. Later maturing males and earlier maturing females may spend a significant amount of time on the bench (i.e., not playing), particularly if the coach places a high priority on winning and/or the league/program has no policies regarding equal playing time. Youth who are not selected to play for more elite soccer programs, or do not receive equal playing time, may begin to doubt their competence as soccer players and as a result may believe that they do not the competence to be successful in soccer. Low perceptions of competence, in turn, can have 
profound psychological and behavioral ramifications during adolescence. Youth who doubt their ability to perform or learn in an achievement arena typically report reduced enjoyment and greater anxiety, and are more likely to drop out of that activity (Weiss and Chaumeton, 1992). Among Norwegian male soccer players 12 to 16 years of age, low perceptions of soccer competence and peer popularity negatively influence persistence in the sport. The relationship was mediated in part by changes in the enjoyment of soccer. Perceptions of competence were most predictive of enjoyment and continued participation among males 14 to 16 years of age (Ommundsen and Vaglum, 199/b).

The implications of the growth and maturity characteristics of young soccer players extend beyond the processes of inclusion and exclusion. It has been alleged that youth soccer coaches affiliated with professional soccer clubs have recruited physicians to help accelerate the growth and maturity of talented yet physically smaller players. Burns (1996), for example, reported that Diego Maradona, the former captain of the Argentinean national soccer team, had undergone treatment to accelerate his growth and maturity while playing for Cebollitas, a youth team affiliated with Argentinos Juniors. It is unclear, however, what exactly the treatment involved. In an interview with Burns (1996), Francisco Cornejo, the head trainer at Cebollitas discussed how Maradona was given a series of vitamins and injections:

"Diego was so small when I took him on that he didn't seem to be strong enough. I wanted Paladino (the physician) to round him off, get him fatter and bigger. So I asked the doctor to give him vitamins and other things to help him develop. Cacho (Palidino) I said to him, you fix him. This boy is going to grow up to be a star" (Burns, 1996, p. 19-20).

On meeting Maradona, Paladino believed that "the boy looked thin not necessarily underdeveloped for his age, but lacking sufficient weight to be a successful sportsman" (Burns, 1996, p. 20). Paladino later declared the treatment a success stating that "When I finished with him (Maradona) he was like a racing colt" (Burns, 1996, p.20).

Chemical substances such as synthetic growth hormone and anabolic steroids have been allegedly used to improve the physical status of young athletes. This approach, however, compromises the physical and psychological health of the child. The administration of anabolic steroids during childhood and adolescence may accelerate sexual and skeletal maturation, and in turn reduce final stature (Johnson and Van de Loo, 2002). Synthetic growth 
hormone, when administered to short children with growth hormone deficiency, results in small gains in stature. However, the health risks and benefits of giving synthetic growth hormone for short children with normal levels of naturally produced growth hormone are unclear. More importantly, the effects of synthetic hormone on the normal growth hormone production are not known.

While chemical substances have been utilized to accelerate the growth and maturation of young. athletes, other more basic methods of manipulation, perhaps, corruption have been used in youth soccer for males. One method used by team managers is the fielding of over-age players to gain an unfair advantage. For example, in the 2001 under-16 Asian youth soccer championship, it was alleged that sixteen of the under 16 players were at least 19 or 20 years old. Hand-wrist radiographs were used to estimate the "ages" of the boys (Sports Illustrated, 200I). The use of hand-wrist radiographs to estimate chronological age in this context has limitations. Boys attain skeletal maturity, on average, by about 18.0 or 19.0 years of age, depending on the method of assessment used (Malina et al., in press). However, one of 10 Mexican youth soccer players (Peña Reyes et al., 1994) and 7 of 43 Portuguese elite youth soccer players (Malina et al., 2000) 15-16 years of age were already skeletally mature, i.e., their estimated ages based on hand-wrist radiographs were 18.0 years. These players would have been eliminated from the competition if their skeletal ages were used, even though their chronological ages based on birth dates were in fact 15 and 16 years! The same trend is also apparent in adolescent ice hockey players (Malina, 1998). This illustrates a major limitation of using radiographs to assess ages of adolescent athletes, and emphasizes the need for accurate birth certificates. The latter, of course, is a problem in areas of the world where birth dates are not systematically recorded. On the other hand, there is also the possibility of team managers, and possibly parents, falsifying birth dates, which has been reported in some youth sport competitions.

A 'win at all costs' approach adopted by some team managers and administrators may carry-over into coaching sessions and create what psychologists have labeled an "ego-involving" or "performance-oriented" climate (Ames, 1992). When an athlete perceives an environment as highly ego-involving, their perception of competence is placed "on the line" each time he/she engages in the activity (i.e., soccer). Accordingly, in such environments continual success is necessary for sustained motivation. Moreover, in order to maintain one's relative standing in competitive settings, individuals may show a lack of concern for justice, fairness, and the welfare of others when ego-involved (Nicholls, 1989). Research conducted with United States Olympic Development youth soccer players suggests that situations 
perceived as ego-involving are associated with less adaptive types of motivation (Treasure et al., 1999) and lower levels of sportspersonship manifest in a lack of respect for rules, officials, and social conventions (Treasure et al., 1998).

\section{PRACTICAL SOLUTIONS}

Those involved in the administration of youth soccer programs and talent development often have relatively little or limited understanding of the processes of growth and maturation, their relationships to athletic performance, and their impact on behavior. Coaches and administrators of youth soccer programs need to be aware of the impact of growth and maturation on the physical and psychological development of young athletes. As noted earlier, youth who are extremely early or late in the timing of adolescence need to be reassured that they are normal, i.e., not different from their peers, and that the maturity-related differences in size and athleticism will eventually be reduced and/or eliminated over time. Adolescents are particularly sensitive to the many changes associated with puberty and must learn to deal with them. The coach is in a privileged role of counselor and confidant, and should provide the support and understanding necessary for youth to adjust to the many changes associated with puberty.

Coaches should be aware of the transient nature of the size and performance advantages associated with variation in maturity status during adolescence so that these characteristics should not be as primary factors for selecting players. These strategies typically favor early over late maturing athletes, and may reduce the likelihood that the players with the most potential for success at the highest level of competition will be still be playing soccer or be available for selection in their late adolescent or early adult years (Malina, 200 I). Late maturing players need to be given equal opportunity to develop their skills and continue to participate in soccer. More importantly, the long term development of the young athlete should be emphasized rather than the immediate gratification of the coach or parents that is often associated with winning at age group competitions.

218 The preceding also applies to female soccer players, with perhaps more concern for the skilled early maturing athlete. Changes in physique and body composition during the growth spurt and sexual maturation may influence athletic performance and perceptions of the self. Adolescent girls, particularly those involved in athletics, are very sensitive to changes in body weight and composition. Coaches need to avoid making comments with regards to body weight, especially in cultures or sports where 'thinness' is perceived as being more desirable. Instead, coaches should focus on issues such as health, 
nutrition, and fitness. Athletes need to be nurtured through these changes in manner that is positive and supportive.

Many soccer programs in the United States have established policies regarding the inclusion and exclusion of young athletes, and equal playing time. Most recreationally-based soccer programs in the United States employ a policy of participation for all. Any child wishing to play soccer is allocated to a team, regardless of their competence. The American Youth Soccer Organization (AYSO) have instituted an "Everyone Plays" rule, requiring each player on a team to play at least one-half of every game. This rule applies to all AYSO teams, (whether regular season teams or teams specially constituted for such event) participating in non-AYSO tournaments or games within or without the U.S.A., regardless of whether the other team, the referee or the sponsors of the tournament or game apply or follow such a rule.

The English Football Association recently implemented changes in the way that young players are grouped for the purpose of talent identification (Simmons and Paull, 200I). A review of the selection criteria for junior squads revealed that many individuals, identified at young ages as having the potential to play at the professional and international, did not make the expected progress. The new strategy for identifying the players with the most potential involved the physical matching of players within selection trials (i.e., players are matched against players of a similar size or physique). Selection was then based upon criteria such as technical skills and tactical awareness. This strategy "...was designed to allow players of more varied physiques to emerge..." on the basis of their skill and tactics (Simmons and Paull, 200 I, p. 677), and to provide equal opportunity for players of all shapes and sizes.

To overcome the impact of individual differences in growth and maturation upon the process of inclusion and exclusion in youth soccer, Brewer et al. (1995) suggests that soccer associations should establish 'current' and 'potential' squads. Current squads should include the best players, both physically and technically, at the time of the selection trials. Potential squads, in comparison, should contain players that are technically gifted yet lacking in physical development. Such a method would help minimize the impact of age and maturity status upon the process of inclusion of exclusion in youth soccer and would increase the likelihood that talented yet physically less gifted players would remain in the system.

\section{REFERENCES}

Ames C (1992). Achievement goals, motivational climate, and motivational processes.

In GC Roberts (Ed). Motivation in Sport and Exercise. Champaign, LL: Human Kinetics. Pp: $161-176$ 
Blyth DA, Simmons RG, Zakin DF (1985). Satisfaction with body image for early adolescent females: The impact of pubertal timing with different school environments. Journal of Youth and Adolescence, 14, 207-225.

Brewer J, Balsom P, Davis J (1995). Seasonal birth distribution amongst European soccer players. Sport, Exercise and Injury, I, I54-157.

Brooks-Gunn J, Ruble DN (1983). The experience of menarche from a developmental perspective. In J Brooks-Gunn and AC Peterson (Eds). Girls at Puberty: Biological and Psychosocial Perspectives. New York: Plenum. Pp: 155-178

Burns I (1996). Hand of God: Life of Maradona, Soccer's fallen star. Guilford, CT: The Lyons Press.

Carter JE, Heath BH (1990). Somatotyping - Development and Applications. Cambridge: Cambridge University Press.

Cumming SP (2002). A bio-psychosocial investigation of self-determined motivation in recreational and travel youth soccer programs. Unpublished doctoral dissertation, Michigan State University, East Lansing.

Faust MS (1983). Alternative constructions of adolescent growth. In J Brooks-Gunn and AC Peterson (Eds.), Girls at puberty: Biological and Psychosocial Perspectives. New York: Plenum. Pp: I05-125

Helsen WF, Starkes JL, Winckel JV (1998). The influence of relative age on success and dropout in male soccer players. American Joumal of Human Biology, 10, 791-798.

Johnson MD, Van de Loo DA (2002). Anabolic steroid use in adolescent athletes. In F Smoll, R Magill, F Ash (Eds). Children in Sport, $3^{\text {rd }}$ edition. Dubuque, IO: Kendall//Hunt Publishing Company. Pp: 83-101

Jones MC, Bayley N (1950). Physical maturing among boys as related to behavior. Joumal of Educational Psychology, 41, 129- 148.

Malina RM (1983). Menarche in athletes: A synthesis and hypothesis. Annals of Human Biology 10, 1-24.

Malina RM (1998). Growth and maturation of young athletes - Is training for sport a factor? In K-M Chan and LJ Micheli (Eds). Sports and Children. Hong Kong: Williams and Wilkins Asia-Pacific. Pp: |33-16 |

Malina RM (200 I). Youth football players: Perspectives from growth and maturation. Insight - The F.A. Coaches Association Joumal, I (5), 27-3I.

Malina RM (2002). The young athlete: Biological growth and maturation in a biocultural context. In F Smoll, R Magill, F Ash (Eds). Children and Youth in Sport, $3^{\text {rd }}$ edition. Dubuque, IO: Kendall//Hunt Publishing Company. Pp: 26I-292.

Malina RM (in press). Growth and maturity status of young soccer (football) players. In T Reilly and M Williams (Eds). Science and Soccer, $2^{\text {nd }}$ edition. London: Routledge.

Malina RM, Bouchard C, Bar-Or OD (in press). Growth, Maturation and Physical Activity, $2^{\text {nd }}$ edition. Champaign, IL: Human Kinetics.

Malina RM, Peña Reyes ME, Eisenmann JC, Horta L, Rodrigues J, Miller R (2000). Height, mass, and skeletal maturity of elite Portuguese soccer players $1 \mathrm{I}-16$ years of age. Journal of Sport Sciences, 18, 685-693.

Mazanti L, Tassanari D, Bergamaschi R, Nanni G, Magnani C, Ghini T, Pini R, Amendola C, Drago E, Cacciari E (1989). Hormonal, auxological, and anthropometric aspects in young football players. In JR Bierich, E Cacciari, S Raiti (Eds). Growth Abnormalities. New York: Raven Press. Pp: 363-369 
Musch J, Hay R (1999). The relative age effect in soccer: Cross-cultural evidence for a systematic discrimination against children born late in the competition year. Sociology of Sport Joumal, 16, 54-64.

Nicholls JG (1989). The competitive ethos and democratic education. Cambridge, MA: Harvard University Press.

Ommundsen $Y$, Vaglum P (199|a). Soccer competition anxiety and enjoyment in young boy players: The influence of perceived competence and significant others' emotional involvement. International Journal of Sport Psychology, 22, 35-49.

Ommundsen $Y$, Vaglum P ( $199 \mid \mathrm{b})$. The influence of low perceived soccer and social competence on later dropout from soccer: a prospective study of young boys. Scandinavian Joumal of Medicine and Science in Sports, I, 180- 188.

Peña-Reyes ME, Cardenas-Barahona E, Malina RM (1994). Growth, physique, and skeletal maturation of soccer players 7-17 years of age. Humanbiologica Budapestinesis, 25, 453-458.

Peterson AC, Taylor B (1980). The biological approach to adolescence: Biological change and psychological adaptation. In J Adelson (Eds). Handbook of Adolescent Psychology. New York: Wiley. Pp: I I7-I55.

Schonfeld W (1964). Body image disturbances in adolescents with inappropriate sexual development. American Joumal of Orthopsychiatry, 34, 493-503.

Siegel SR (1995). Growth and maturity status of female soccer players from late childhood through early adulthood. Unpublished master's thesis, University of Texas, Austin.

Siegel SR, Katzmaryzk PT, Malina RM (1996). Somatotypes of female soccer players 10-24 years of age. In E Bodzsar, C Susanne (Eds). Studies in Human Biology. Budapest: Eotvos University Press. Pp: 277-185

Simmons C, Paull GC (2001). Season of birth bias in association football. Journal of Sport Sciences, 19, 677-686.

Sports Illustrated (200I). Cheating does not pay: Asia bans teams, players for over-age infractions (May 10).

http://sportsillustrated.cnn.com/soccer/news/200 |/05//0/asia_rdp/index.html.

Treasure DC, Roberts GC, Standage M (1998). Predicting sportspersonship: Interaction of achievement goal orientations and perceptions of the motivational climate. Journal of Sport and Exercise Psychology, 20, SI 2.

Treasure DC, Standage M, Lochbaum M (1999). Perceptions of the motivational climate and situational motivation in elite youth sport. Paper presented at the annual meetings of the Association for the Advancement of Applied Sport Psychology. Bannf, Alberta, Canada (September).

Weiss MR, Chaumeton N (1992). Motivational orientations in sport. In TS Horn (Ed), Advances in Sport Psychology. Champaign, IL: Human Kinetics. Pp: 6I-99

Weiss MR, Glenn SD (1992). Psychological development and females' sport participation: An interactional perspective. Quest, 44, I38-57. 
Série

Investigacão

Coimbra

Imprensa da Universidade

2004 